\title{
Immunomodulatory effects of the intake of fermented milk with Lactobacillus casei DN114001 in lactating mothers and their children
}

\author{
Adriana Ortiz-Andrellucchi ${ }^{1}$, Almudena Sánchez-Villegas ${ }^{1}$, Carlos Rodríguez-Gallego ${ }^{2}$, Angelina Lemes ${ }^{3}$, \\ Teresa Molero ${ }^{3}$, Adela Soria ${ }^{4}$, Luis Peña-Quintana ${ }^{1,5}$, Milagrosa Santana ${ }^{5}$, Octavio Ramírez ${ }^{6}$, José García ${ }^{6}$, \\ Félix Cabrera ${ }^{1}$, José Cobo $^{7}$ and Lluís Serra-Majem ${ }^{1 *}$ \\ ${ }^{1}$ Department of Clinical Sciences, University of Las Palmas de Gran Canaria, PO Box 550, 35080-Las Palmas de Gran Canaria, Spain \\ ${ }^{2}$ Department of Immunology, Hospital Universitario de Gran Canaria Dr Negrín, Las Palmas, Spain \\ ${ }^{3}$ Haematology Service, Hospital Universitario de Gran Canaria Dr Negrín, Las Palmas, Spain \\ ${ }^{4}$ Biochemistry Service, Hospital Universitario Insular, Las Palmas, Spain \\ ${ }^{5}$ Unidad de Gastroenterología y Nutrición Infantil, Hospital Universitario Materno-Infantil de Canarias, Las Palmas, Spain \\ ${ }^{6}$ Department of Obstetrics and Gynaecology, Hospital Universitario Materno-Infantil de Canarias, Las Palmas, Spain \\ ${ }^{7}$ Danone S. A., Barcelona, Spain \\ (Received 27 June 2007 - Revised 22 January 2008 - Accepted 23 January 2008 - First published online 17 March 2008)
}

\begin{abstract}
The healthy action of probiotics is not only due to their nutritional properties and their influence on the gastrointestinal environment, but also to their action on the immune system. The aim of the present study was to determine if 6 weeks of probiotic intake would be able to modulate the immune system in women who had recently delivered and were breast-feeding. The design consisted of a randomised, controlled and double-blind nutritional intervention study with parallel groups with a sample size of 104 women. The main variable is the $\mathrm{T}$ helper type 1/T helper type 2 (Th1/Th2) profile determined by measuring interferon- $\gamma(\mathrm{Th} 1)$ and IL-4 (Th2) values in peripheral blood by flow cytometry. The modifications of cytokines were evaluated in maternal milk by cytometric bead array in a flow cytometer and ELISA at three stages of breast-feeding: colostrum, early milk (10 d) and mature milk ( $45 \mathrm{~d}$ ). Additionally, the anthropometry and infectious and allergic episodes in the newborn were followed up throughout the first 6 months of life. After the consumption of milk fermented with Lactobacillus casei during the puerperium, we observed a nonsignificant increase in T and B lymphocytes and a significant increase in natural killer cells. A decrease in the pro-inflammatory cytokine TNF- $\alpha$ in maternal milk and fewer gastrointestinal disturbances were also observed in the breast-fed child of the mothers who consumed $L$. casei. The intake of milk fermented with $L$. casei during the lactation period modestly contributes to the modulation of the mother's immunological response after delivery and decreases the incidence of gastrointestinal episodes in the breast-fed child.
\end{abstract}

Probiotics: Postpartum period: Clinical trials: Lactobacillus casei DN114001: Human milk: Cytokines: Immune response

It is generally acknowledged that pregnancy is associated with a modification of the $\mathrm{T}$ helper type $1 / \mathrm{T}$ helper type 2 (Th1/Th2) balance toward a Th2 profile ${ }^{(1)}$. According to this interpretation, Th1 prevalence would be associated with an increase in spontaneous abortions ${ }^{(2)}$. The data on which this interpretation is based come from three types of studies: studies carried out in peripheral blood, studies carried out in placental or endometrial tissue and experimental studies in gestational mice ${ }^{(3-7)}$.

Few data exist about the modifications of the immune response during the puerperium. In general, it has been observed that the Th1/Th2 balance ${ }^{(3,8)}$ improves during the lactation period. Moreover, a decrease in the B lymphocytes (positive CD19) has been observed during this period, having a specific connection with prolactin levels ${ }^{(9,10)}$.

The dependence on adequate nutritional status is an important aspect of the immune response during the puerperium ${ }^{(11)}$.
Probiotics are considered functional foods because they exert different actions on organs and systems. In addition, their components have nutritional activity. The lactic acid bacteria are the most commonly used micro-organisms in probiotic products. The bacterial strains most used as probiotics are Lactobacillus and Bifidobacterium. There is ample literature on the healthy action of lactic acid bacteria and their fermentation products ${ }^{(12-16)}$. These effects are not only due to their nutritional properties and their influence on the gastrointestinal environment, but also to their action on the immune system $^{(17)}$. The biological effects of Lactobacillus casei on the intestinal membrane and flora are diverse ${ }^{(18)}$. However, its effect on the systemic immune response has scarcely been evaluated. Depending on the methodology, the administration of this bacterium or its biological products may not be implied in the modification of the systemic immune response $^{(19)}$, or could alternatively stimulate the Th1.

Abbreviations: AV, absolute variation; IFN, interferon; NK, natural killer; Tc1, cytotoxic T cell type 1; Tc2, cytotoxic T cell type 2; Th1, T helper type 1; Th2,

T helper type 2; TFG, transforming growth factor.

* Corresponding author: Dr Lluís Serra-Majem, fax +34928 453475, email lserra@dcc.ulpgc.es 
Thus, the intrapleural administration of these bacteria induces the production of several cytokines such as interferon (IFN)- $\alpha$, TNF- $\alpha$ and IL-1, diminishing the growth of tumours in an experimental model in mice ${ }^{(20)}$. In another experimental study, the interaction of $L$. casei with mouse splenocyte cells in vivo and in vitro stimulated the Th1 response (production of IL-12 and IFN- $\gamma)^{(21)}$. Moreover, it has been reported that the oral administration of $L$. casei stimulates the Th1 response, thus protecting the host against the influenza virus ${ }^{(22)}$ or Trichinella spiralis nematode ${ }^{(23)}$. Finally, in a smaller study, the oral administration of this bacterium increased the activity of the natural killer (NK) cells ${ }^{(24)}$.

The present study was designed to determine if probiotic intake (milk fermented with L. casei DN114001) over a 6-week interval from postnatal day 3 to day 45 would be able to modulate the immune system in women who had recently delivered and were breast-feeding. In addition, the role of probiotic intake on cytokines in maternal milk and on newborn health variables was also ascertained.

\section{Subjects and methods}

\section{Subjects}

The present prospective study was based on 104 pregnant women aged 18-40 years. Sample size was estimated considering an immunological response of $90 \%$ in the intervention group and of $70 \%$ in the control group. With $5 \%$ level of significance and $80 \%$ of power, fifty-two individuals were needed in each group considering a non-participation rate of $10 \%$. Women were included if they had good general health status and a low obstetric risk, with a normal delivery at the Hospital Universitario Materno Infantil de Canarias resulting in the birth of a healthy baby. Subjects with pre-existing clinical conditions such as diabetes, hypertension, autoimmune diseases, asthma, allergy, renal diseases, hepatic diseases, antecedents of viral, bacterial or protozoan infection, as well as those with multiple pregnancy, high-risk pregnancy, anaemias with $\mathrm{Hb}$ below $10.5 \%$, and those who smoked more than ten cigarettes per $\mathrm{d}$ were excluded from the study. Women completed a socio-demographic and lifestyle questionnaire. Additional, anthropometric measurements and infectious and allergic episodes in the newborn were evaluated during the first 6 months of life. The study protocol is summarised in Fig. 1. All subjects were well informed about the study and agreed to participate. The Ethics Committee of the Hospital Universitario Materno Infantil de Canarias revised and approved the study protocol. Informed consent of all participants was obtained.

The participants were randomised after delivery to receive milk fermented with $L$. casei or placebo. The culture used was L. casei DN-114001. The international culture collection number was Americal Type Culture Collection (ATCC) 334. Group assignment was carried out according to the entrance order in the study through a randomised list divided into four strata: primiparous of age 18-24 years, primiparous of age 25-40 years, multiparous of age 18-24 years or multiparous of age 25-40 years. Randomisation was performed using an allocation sequence that was computer generated by an independent firm, Biomedical Systems Group S. A. (Barcelona, Spain). The main investigator enrolled all the patients. The randomisation procedure was conducted by an external collaborator of the investigation team. All the participants were identified with an alphanumeric code. The investigators did not have access to the allocation sequence until the database was closed. Sealed envelopes for each participant were

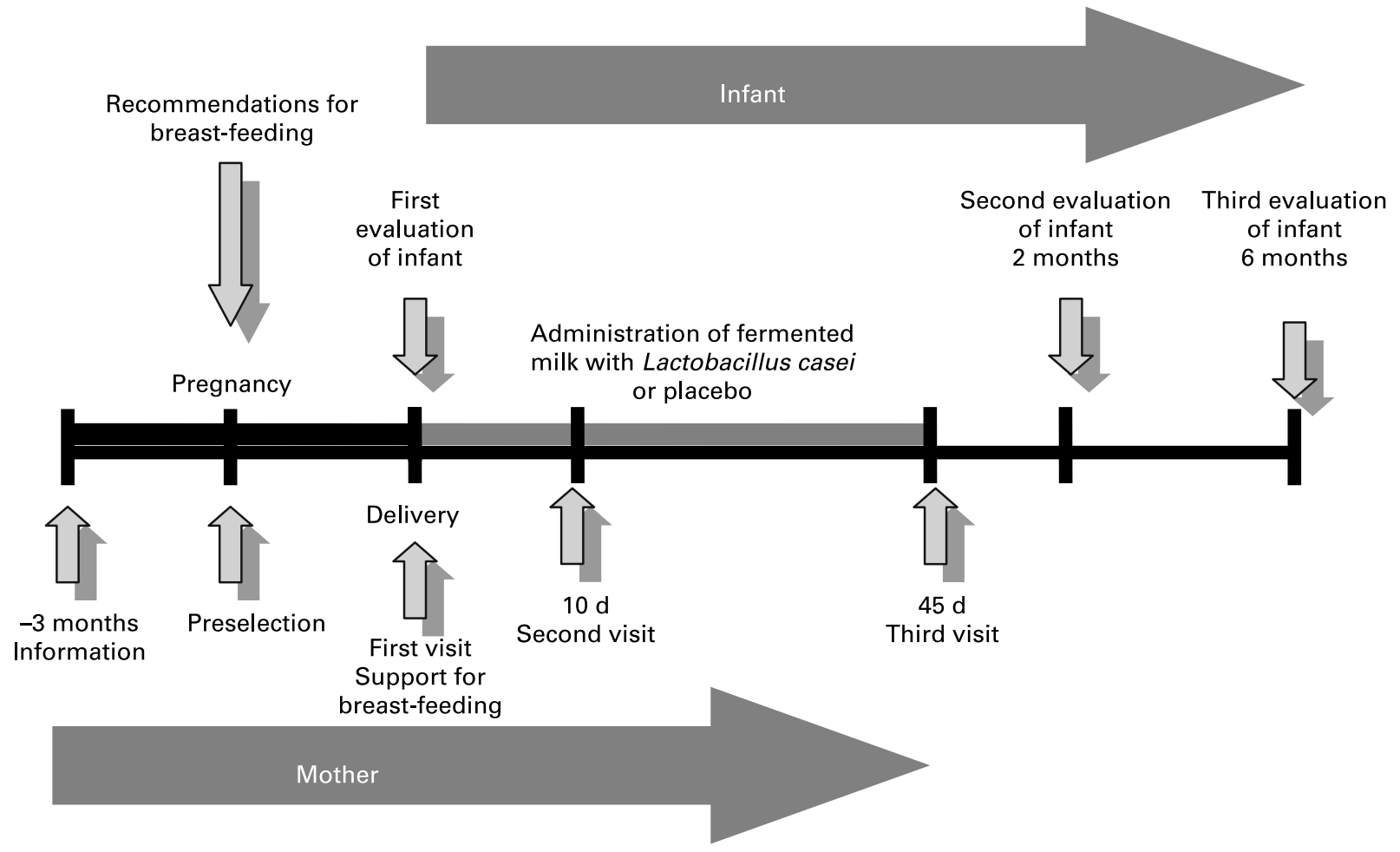

Fig. 1. Study design. 
kept in case of emergency situations, but the blinding was not broken during the study follow-up. Control and intervention products presented similar sensory properties to maintain double-blind status. Therefore, the placebo is the same product used for the intervention group but subjected to a $\beta$ radiation process. The dose of the radiation was $4.5 \mathrm{kGy}$. Hence, the $L$. case $i$ was inactivated and not viable in the placebo, but the inactivated cells were retained. The administration of the study products (milk fermented with $L$. casei or placebo) consisted of consumption three times per d during 6 weeks. Initiation of the fermented milk intake occurred on the day following the first extraction of blood and breast milk samples (colostrum). A diary was given to all mothers to write down the fermented milk intake per d during the study period.

The final sample of this prospective study was based on 104 pregnant women. Forty-five received placebo and fifty-nine received fermented milk with $L$. casei DN114001. The follow-up rate was $89.4 \%$. The main causes for non-participation during follow-up are shown in Fig. 2. Non-attendance to a visit was the only cause of a lack of infant participation.

\section{Analyses of peripheral blood samples}

Three peripheral blood samples were obtained: at 3,10 and $45 \mathrm{~d}$ postpartum.

Analyses of interferon- $\gamma$ - and IL-4-producing T cells. The assessment of immunological parameters was carried out in the Immunology Laboratory of the Hospital Universitario Dr Negrín de Gran Canaria. Using conjugated monoclonal antibodies and a flow cytometer, we studied the changes in the immune profile of postpartum women. Peripheral blood for whole-blood activation assays was collected into sodium heparin Vacutainer ${ }^{\circledR}$ tubes (Becton Dickinson, MeylanCedex, France). Whole-blood cultures were stimulated in Roswell Park Memorial Institute (RPMI)-1640 medium (Biochrom, Berlin, Germany) with phorbol myristate acetate (10 ng/ml; Sigma Chemical Co., St Louis, MO, USA) and ionomycin $(1 \mu \mathrm{g} / \mathrm{ml}$; Sigma Chemical Co.) in the presence of brefeldin-A $(10 \mu \mathrm{g} / \mathrm{ml}$; Sigma Chemical Co.) for $4 \mathrm{~h}$ at $37^{\circ} \mathrm{C}$ in a $5 \% \mathrm{CO}_{2}$ atmosphere. The following murine conjugated monoclonal antibodies to human lymphocyte cell-surface antigens were used: CD3-PerCP, CD8-fluorescein isothiocyanate (FITC), CD45-allophycocyanin (APC), and isotypic-matched irrelevant antibodies (all from BD Biosciences, San Jose, CA, USA). Whole-blood cultures were mixed and incubated for $15 \mathrm{~min}$ at room temperature in the dark with the indicated monoclonal antibodies. For fixation and permeabilisation, the Fix \& Perm reagent (FIX \& PERM $^{\circledR}$ Cell Permeabilization Kit; Caltag, Burlingame, CA, USA) was used according to the manufacturer's protocols. For intracellular labelling of cytokines, Anti-human IFN$\gamma$-phycoerythrin (PE), Anti-human IL-4-PE and PE-labelled isotypic-matched irrelevant antibodies (BD Biosciences, San Jose, CA, USA) were used. Cell fluorescence was analysed in a FACSCalibur ${ }^{\circledR}$ flow cytometer (BD Biosciences). Lymphocytes were gated by forward and side scatter and panleucocyte (CD45; BD Biosciences) marker expression, and at least 20000 events were analysed. The collected data were analysed using CellQuest Macintosh software (Apple Computer, Inc., Cupertino, CA, USA) and presented as percentages.

Determining the percentage of IFN- $\gamma$ - and IL-4-producing $\mathrm{T}$ cells was carried out by gating on $\mathrm{CD} 3^{+} \mathrm{CD} 8^{+}$and $\mathrm{CD}^{+} \mathrm{CD}^{-}$lymphocytes. The Th1/Th2 cell ratio was

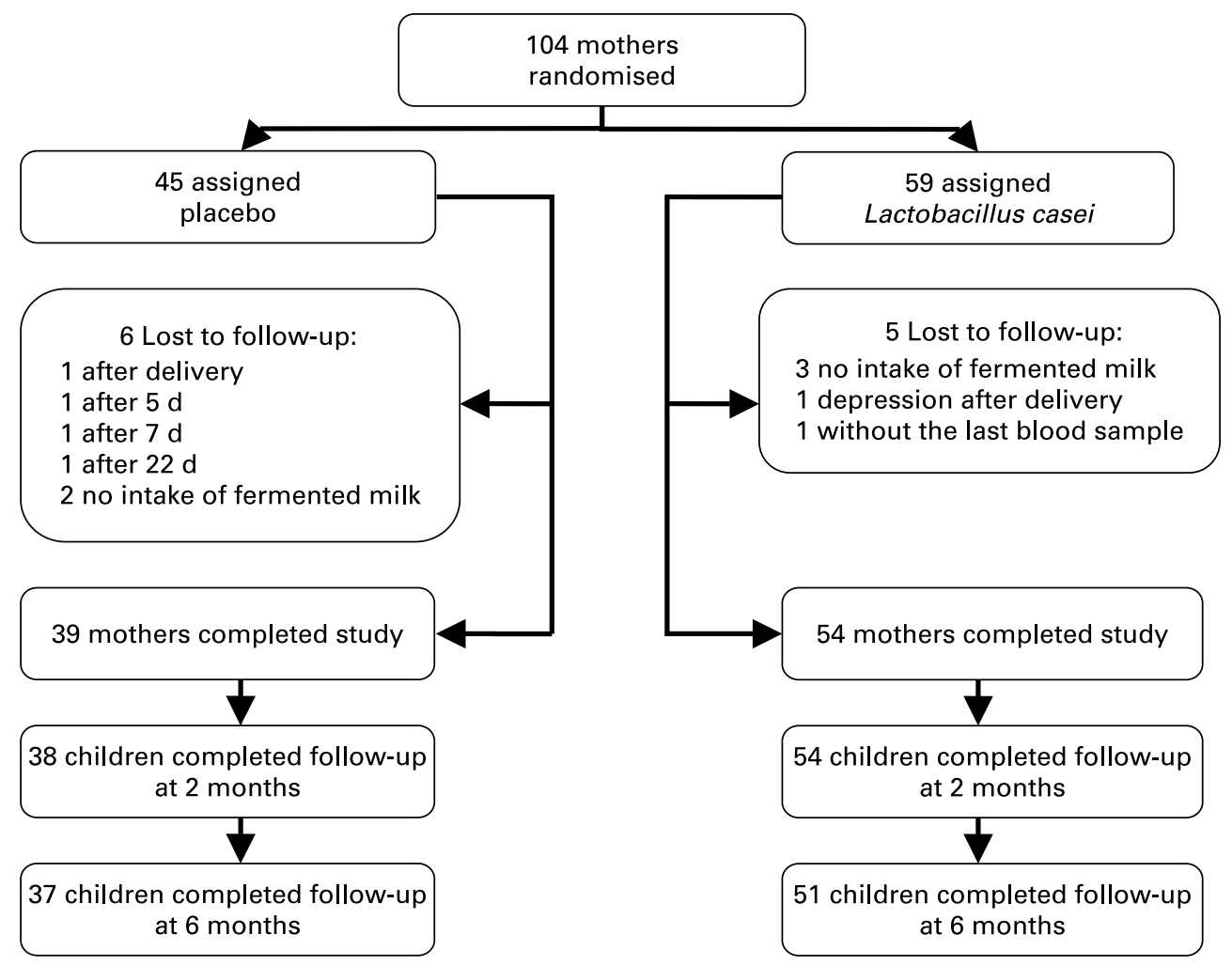

Fig. 2. Trial profile. 
analysed by calculating the percentage of INF- $\gamma^{+}$-producing $\mathrm{CD}^{-} \mathrm{T}$ cells and the percentage of $\mathrm{IL}-4^{+}$-producing $\mathrm{CD} 8^{-}$ $\mathrm{T}$ cells. The cytotoxic $\mathrm{T}$ cell type 1/cytotoxic $\mathrm{T}$ cell type 2 $(\mathrm{Tc} 1 / \mathrm{Tc} 2)$ ratio was assessed by analysing the percentage of INF- $\gamma^{+}$-producing $\mathrm{CD}^{+} \mathrm{T}$ cells and the percentage of $\mathrm{IL}-4^{+}$-producing $\mathrm{CD}^{+} \mathrm{T}$ cells. Since the CD4 molecule is down-regulated by phorbol myristate acetate plus ionomycin activation, $\mathrm{CD} 8^{-} \mathrm{CD}^{+} \mathrm{T}$ cells were gated for the analysis of CD4 $\mathrm{T}$ cells. The absolute counts of INF- $\gamma^{+}$-producing cells and of IL- $4^{+}$-producing cells in whole blood were calculated as the products of the absolute $\mathrm{CD} 8^{-}$or $\mathrm{CD}^{+} \mathrm{T}$ cell count and the percentages of each cytokine-secreting cell population.

Analyses of lymphocyte subsets. The Haematology Laboratory of the Hospital Universitario Dr Negrín de Gran Canaria analysed haematological parameters in peripheral blood samples collected with EDTA. Routine blood haematology (number of erythrocytes, Hb concentration, packed cell volume, mean corpuscular volume, mean corpuscular $\mathrm{Hb}$, mean corpuscular $\mathrm{Hb}$ concentration, erythrocyte distribution width, number of leucocytes, lymphocytes, monocytes, neutrophils, eosinophils and basophils) was assessed using an automated haematology analyser (Cell-Dyn $4000^{\circledR}$; Abbott Diagnostics, Santa Clara, CA, USA).

The following lymphocyte subsets were measured: mature $\mathrm{T}$ cell $\left(\mathrm{CD}^{+}\right)$; helper $\mathrm{T}$ cell $\left(\mathrm{CD}^{+}{ }^{+} \mathrm{CD}^{+}{ }^{+}\right)$; cytotoxic/supressor $\mathrm{T}$ cell $\left(\mathrm{CD}^{+} \mathrm{CD}^{+}\right)$; B cells $\left(\mathrm{CD} 19^{+}\right)$; NK cells $\left(\mathrm{CD} 3^{-} \mathrm{CD}^{+} 6^{+}\right)$; NK T-like cells $\left(\mathrm{CD}^{+}{ }^{+} \mathrm{CD} 56^{+}\right)$. EDTA whole blood cells were incubated with the monoclonal antibodies combination: CD3FITC/CD8PE/CD45PerCP/CD4APC, and CD3FITC/ CD56PE/CD45PerCP/CD19APC (all from BD Biosciences, San Jose, CA, USA). After 10 min incubation at room temperature in the dark, erythrocyte lyses was performed. Samples were then washed with PBS (Sigma, St Louis, MO, USA) and acquired on a cytometer (FACSort ${ }^{\circledR}$; BD Biosciences). Analysis was carried out on the Paint-a-gate software (BD Biosciences). Lymphocytes were gated by forward and side scatter and panleucocyte (CD45; BD Biosciences) marker expression.

The absolute counts of lymphocyte subpopulations in the whole blood were calculated as the products of the absolute lymphocyte counts and the percentages of each lymphocyte subpopulation.

Analyses of complement components and immunoglobulins. The serum peripheral blood samples were analysed in the Biochemistry Laboratory of the Hospital Universitario Insular de Gran Canaria. The following parameters were assessed in serum from clotted samples: complement components $\mathrm{C} 3$ and $\mathrm{C} 4, \operatorname{Ig} \mathrm{A}, \operatorname{IgE}, \operatorname{IgM}, \operatorname{IgG}$ and the subclass $\operatorname{IgG} 1, \operatorname{IgG} 2$, $\mathrm{IgG} 3$ and $\mathrm{IgG} 4$, all determined by nephelometry (Behring nephelometer analyser; Dade-Behring, Marburg, Germany).

\section{Analyses of breast milk samples}

Collection and processing. Three samples of maternal milk were determined: colostrum (within $72 \mathrm{~h}$ after delivery; $n$ 104), early milk ( $10 \mathrm{~d}$ postpartum; $n$ 99) and mature milk (45 d postpartum; $n$ 91). Colostrum samples were obtained at the Hospital Universitario Materno Infantil de Gran Canaria by manual extraction, and the early and mature milk were obtained at the mother's home with an electric breast-pump. All samples were collected in sterile plastic tubes and stored at $-20^{\circ} \mathrm{C}$ until analysis. After thawing, the fatty layer and the cellular elements of the breast milk were removed by two centrifugations. Some of the resulting translucent whey was immediately used for measurement of transforming growth factor (TGF)- $\beta$, and the rest was stored in samples in plastic tubes at $-20^{\circ} \mathrm{C}$.

IgA and cytokine assays. The concentrations of TGF- $\beta 1$ and TGF- $\beta 2$ in the breast milk aqueous phase were analysed using commercial ELISA kits (R\&D Systems Inc., Minneapolis, MN, USA) according to the manufacturer's protocols. Before assay for TGF- $\beta 1$ the sample had to be treated with $1 \mathrm{M}-\mathrm{HCl}$ to adjust to $\mathrm{pH} 3$; the acidified sample was incubated for $15 \mathrm{~min}$ at room temperature and neutralised with $1 \mathrm{M}-\mathrm{NaOH}$ and immediately tested. The treatment was performed to activate latent TGF- $\beta 1$ to the immunoreactive form $^{(25)}$. IL-1 $\beta$, IL-6, IL-8, IL-10, IL-12 and TNF- $\alpha$ contents in the breast milk aqueous phase were quantified by means of $\mathrm{BD}^{\mathrm{TM}}$ Cytometric Bead Array (CBA) by flow cytometry, using a Human Inflammation CBA kit (Becton Dickinson Biosciences, San Diego, CA, USA). The minimum detectable concentrations of each cytokine were $1.90 \mathrm{pg} / \mathrm{ml}$ (IL-12), $7.2 \mathrm{pg} /$ $\mathrm{ml}$ (IL-1 $\beta$ ), $2.5 \mathrm{pg} / \mathrm{ml}$ (IL-6), $3.3 \mathrm{pg} / \mathrm{ml}$ (IL-10) and $3.7 \mathrm{pg} / \mathrm{ml}$ $(\mathrm{TNF}-\alpha)$. The concentration of $\operatorname{IgA}$ was determined by nephelometry (Behring nephelometer analyser; Dade-Behring, Marburg, Germany).

\section{Infant follow-up}

The first evaluation was carried out $72 \mathrm{~h}$ after delivery. We evaluated the anthropometric characteristics of the newborn (weight, stature, head circumference, neonatal period, neonatal screening, Apgar scores). Additionally, anthropometric measurements and respiratory episodes (cold, otitis, pharyngitis, laryngitis, bronchitis, pneumonia), gastrointestinal symptoms (oral candidiasis, regurgitation, diarrhoea, colic, constipation), dermatitis and allergic episodes in the newborn were collected at 2 and 6 months. These evaluations were carried out at the Hospital Universitario Materno Infantil de Canarias. Moreover, mothers received a diary to write down the type of feeding, the medication used and the infant's health problems during the study.

\section{Statistical analysis}

At baseline, qualitative variable distribution was tested through the $\chi^{2}$ test. Student's $t$ test was used to assess differences in quantitative variables. The analysis of the data was carried out on the intention-to-treat population. Because of the lack of normality in most of the variables, the association between different women's characteristics and the immune profile was assessed though non-parametric Mann-Whitney $U$ tests. Data were expressed as the median plus the interquartile range, absolute variation (AV2: visit 2 - visit 1; AV3: visit 3 - visit 1 ; AV4: visit 3 - visit 2 ) and percentage variation (PV2: $100 \times($ visit 2 - visit 1)/visit 1; PV3: $100 \times($ visit $3-$ visit 1$) / v i s i t ~ 1)$. A value corresponding to half the cut-off value was assigned to those milk samples that had a concentration below the cut-off. Milk cytokine concentrations were expressed in $\mathrm{pg} / \mathrm{ml}$ and $\operatorname{IgA}$ concentrations were expressed in mg/l. A significance level of $P<0.05$ 
was applied for all the tests. Data were analysed with SPSS (version 12.0; SPSS Inc., Chicago, IL, USA).

\section{Results}

Baseline characteristics of the mother and birth are presented in Table 1. Baseline biological parameters were similar for both the placebo and L. casei groups (Table 2).

Table 3 shows the effects of milk supplementation with L. casei on several biological parameters. No significant differences were observed between the $L$. casei and control groups in the absolute change of Th1/Th2 and Tc1/Tc2 profiles over the 6-week period. The $L$. casei group showed a higher number of $\mathrm{CD}^{+} \mathrm{T}$ cells (AV: 316 cells/ $\mu \mathrm{l}$ and 140 cells $/ \mu \mathrm{l}$ for $L$. casei and control groups, respectively) and $\mathrm{CD}^{+} \mathrm{T}$ cells (AV: 98 cells $/ \mu \mathrm{l}$ and $44 \mathrm{cells} / \mu \mathrm{l}$ for L. casei and control groups, respectively) at $45 \mathrm{~d}$ postpartum, although this tendency was not statistically significant. B cells $\left(\mathrm{CD} 19^{+}\right)$showed a non-significant increase between 10 and $45 \mathrm{~d}$ postpartum with an AV of 17.5 cells $/ \mu l$ in the L. case $i$ group and 6.5 cells $/ \mu 1$ in the control group. The treatment effects on NK cells $\left(\mathrm{CD} 3^{-} \mathrm{CD} 6^{+}\right)$were statistically significant when the AV of NK cells were measured at 10 and $45 \mathrm{~d}$ postpartum (AV: $18.5 \mathrm{cells} / \mu \mathrm{l}$ and -13 cells $/ \mu \mathrm{l}$ for $L$. casei and control groups, respectively; $P=0 \cdot 026$ ) (Fig. 3). There was no significant treatment effect on the total leucocyte changes over the 6-week study. The treatment effect on erythrocyte count changes over the 6-week study was statistically significant for both groups (AV: $18.5 \times 10^{6} / \mu \mathrm{l}$ and $10.6 \times 10^{6} / \mu \mathrm{l}$ for $L$. casei and control groups, respectively;

Table 1. Mother and birth baseline characteristics in Lactobacillus casei (LC) or placebo groups

(Mean values and standard deviations or proportions)

\begin{tabular}{|c|c|c|c|c|c|}
\hline & \multicolumn{2}{|c|}{$\mathrm{LC}(n 59)$} & \multicolumn{2}{|c|}{$\begin{array}{c}\text { Placebo } \\
(n 45)\end{array}$} & \multirow[b]{2}{*}{$P$} \\
\hline & Mean & SD & Mean & SD & \\
\hline Age (years) & $29 \cdot 4$ & 4.5 & $30 \cdot 2$ & $4 \cdot 2$ & $0.343^{*}$ \\
\hline BMI before pregnancy $\left(\mathrm{kg} / \mathrm{m}^{2}\right)$ & $23 \cdot 0$ & 3.3 & $23 \cdot 3$ & 3.5 & $0.640^{*}$ \\
\hline Gestation (weeks) & $40 \cdot 2$ & $1 \cdot 1$ & $39 \cdot 7$ & 1.5 & $0.077^{\star}$ \\
\hline Newborn weight (kg) & $3 \cdot 3$ & 0.4 & $3 \cdot 2$ & 0.4 & $0.333^{*}$ \\
\hline Newborn height (cm) & $50 \cdot 3$ & 1.9 & $50 \cdot 5$ & $2 \cdot 2$ & $0.946^{*}$ \\
\hline Educational level (\%) & & & & & $0.325 \dagger$ \\
\hline Primary & \multicolumn{2}{|c|}{$16 \cdot 9$} & \multicolumn{2}{|c|}{$27 \cdot 3$} & \\
\hline Secondary & \multicolumn{2}{|c|}{$49 \cdot 2$} & \multicolumn{2}{|c|}{$36 \cdot 4$} & \\
\hline University & \multicolumn{2}{|c|}{33.9} & \multicolumn{2}{|c|}{$36 \cdot 4$} & \\
\hline Number of children (\%) & & & & & $0.933 \dagger$ \\
\hline Primiparous & \multicolumn{2}{|c|}{$76 \cdot 3$} & \multicolumn{2}{|c|}{$75 \cdot 6$} & \\
\hline Multiparous & \multicolumn{2}{|c|}{$23 \cdot 7$} & \multicolumn{2}{|c|}{$24 \cdot 4$} & \\
\hline Physical activity (\%) & & & & & $0.801 \dagger$ \\
\hline Sedentary & \multicolumn{2}{|c|}{$28 \cdot 8$} & \multicolumn{2}{|c|}{$31 \cdot 8$} & \\
\hline Moderate & \multicolumn{2}{|c|}{$47 \cdot 5$} & \multicolumn{2}{|c|}{$40 \cdot 9$} & \\
\hline Active & \multicolumn{2}{|c|}{$23 \cdot 7$} & \multicolumn{2}{|c|}{$27 \cdot 3$} & \\
\hline Smoking during pregnancy (\%) & \multicolumn{2}{|c|}{8.5} & \multicolumn{2}{|c|}{$17 \cdot 8$} & $0.245 \dagger$ \\
\hline Miscarriage risk (\%) & \multicolumn{2}{|c|}{$25 \cdot 9$} & \multicolumn{2}{|c|}{24.4} & $0.870 \dagger$ \\
\hline Normal delivery (\%) & \multicolumn{2}{|c|}{$78 \cdot 0$} & \multicolumn{2}{|c|}{$82 \cdot 2$} & $0.592 \dagger$ \\
\hline Fetal discomfort (\%) & \multicolumn{2}{|c|}{1.7} & \multicolumn{2}{|c|}{2.3} & $0.833 \dagger$ \\
\hline Apgar score (5 min) (\%) & & & & & $0.693 \dagger$ \\
\hline 8 & \multicolumn{2}{|c|}{$5 \cdot 2$} & \multicolumn{2}{|c|}{$2 \cdot 2$} & \\
\hline 9 & \multicolumn{2}{|c|}{$31 \cdot 0$} & \multicolumn{2}{|c|}{$35 \cdot 6$} & \\
\hline 10 & \multicolumn{2}{|c|}{$63 \cdot 8$} & \multicolumn{2}{|c|}{$62 \cdot 2$} & \\
\hline
\end{tabular}

${ }^{*} P$ value obtained using the $t$ test.

$\dagger P$ value obtained using the $\chi^{2}$ test.
$P=0 \cdot 041)$. However, treatment was not associated to a significant change in other haematological parameters over the 6-week study (data not shown). No significant differences between the treatment and the control groups were found for changes in plasma immunoglobulin concentration over the 6 weeks, except for $\mathrm{IgG} 4$ concentration at $10 \mathrm{~d}$ postpartum, where a significant effect of the treatment on the AV of IgG4 was observed (36 and $63 \mathrm{mg} / 1$ for $L$. casei and control groups, respectively; $P=0 \cdot 041)$. There was no significant treatment effect on the changes of complement components $\mathrm{C} 3$ and $\mathrm{C} 4$ over the 6-week period.

For the entire study period, in general, no significant differences were found for changes in TGF- $\beta 1$, TGF- $\beta 2$, IL- $1 \beta$, IL-6, IL-8, IL-12 and IgA in the breast milk aqueous phase. We observed a significant difference at $45 \mathrm{~d}$ postpartum for IL-10 (percentage variation -5.8 and $1.1 \%$ for $L$. casei and control groups, respectively; $P=0.014$ ) and TNF- $\alpha$ (percentage variation -31.7 and $-1.6 \%$ for $L$. casei and control groups, respectively; $P=0.002$ ). However, it should be noted that TNF- $\alpha$ concentrations were detected only in $64 \%$ of colostrum samples, in $40 \%$ of early milk samples and in $30 \%$ of mature milk. The percentage of positive samples for IL-10 concentrations was $58 \%$ in colostrum, $20 \%$ in early milk and $18 \%$ in mature milk. Figure 4 shows the percentage variation of TGF- $\beta 1$, TGF- $\beta 2$, TNF- $\alpha$ and IL-10 in breast milk in $L$. casei and placebo groups.

In reference to the growth of the newborns during the study period, we note that there were no significant differences between groups in relation to weight (data not shown). Information about the rest of the parameters collected during the infant 6-month follow-up period is summarised in Table 4. We observed that $L$. casei consumption was associated with a lower incidence of gastrointestinal episodes and a lower rate of medication in infants during the period from 2 to 6 months.

\section{Discussion}

The present study found that the consumption of milk fermented with $L$. casei during the puerperium showed a trend of modulating the immune response. After the consumption of milk fermented with $L$. casei during the puerperium we observed a significant increase of NK cells and a non-significant increase of T and B lymphocytes. No significant differences were observed between the $L$. casei and control groups in the absolute change of Th1/Th2 and Tc1/Tc2 profiles over the 6-week period. These data are contradictory to other reports where probiotic consumption was observed to produce a rise in IFN- $\gamma^{(26)}$, thus increasing the Th1/Th2 profile. Nevertheless, in these studies the concentration of IFN- $\gamma$ was directly quantified. We measured the percentage of INF- $\gamma^{+}$-producing $\mathrm{CD} 8^{-}$and $\mathrm{CD} 8^{+} \mathrm{T}$ cells. However, since a non-significant increase of $\mathrm{CD}^{+}$and $\mathrm{CD}^{+} \mathrm{T}$ cells in the intervention group was observed, an alteration of the relative values of $\mathrm{CD}^{+}$and $\mathrm{CD}^{-} \mathrm{T}$ cells could occur. In order to minimise this effect, the absolute values of INF- $\gamma$ producing $\mathrm{CD}^{-}$and $\mathrm{CD}^{+} \mathrm{T}$ cells were calculated, but no differences in the $\mathrm{Th} 1 / \mathrm{Th} 2$ and $\mathrm{Tc} 1 / \mathrm{Tc} 2$ profiles were observed either. In addition, a non-significant increase of the $\mathrm{CD}^{+}{ }^{+} \mathrm{CD} 6^{+}$subpopulation was also observed in the L. casei group. For the analysis of INF- $\gamma$ - and IL-4-producing T cells we gated on $\mathrm{CD}^{+}{ }^{+} \mathrm{CD} 8^{-}$and $\mathrm{CD} 3^{+} \mathrm{CD} 8^{+} \mathrm{T}$ cells. Therefore, 
Table 2. Baseline biological parameters in Lactobacillus casei (LC) and placebo groups

(Median values and 25th to 75th percentiles (p25-p75))

\begin{tabular}{|c|c|c|c|c|c|}
\hline \multirow[b]{2}{*}{ Parameters } & \multicolumn{2}{|c|}{ LC $(n 59)$} & \multicolumn{2}{|c|}{ Placebo (n 45) } & \multirow[b]{2}{*}{$P^{\star}$} \\
\hline & Median & p25-p75 & Median & p25-p75 & \\
\hline Th1/Th2 profile† & $4 \cdot 4$ & $3 \cdot 6-5 \cdot 5$ & $3 \cdot 8$ & $3 \cdot 0-5 \cdot 4$ & 0.147 \\
\hline Tc1/Tc2 profileł & $22 \cdot 7$ & $10 \cdot 7-37 \cdot 8$ & $21 \cdot 0$ & $13 \cdot 4-53.5$ & 0.490 \\
\hline \multicolumn{6}{|c|}{ Lymphocyte subsets (cells/ $\mu \mathrm{l}$ ) } \\
\hline CD3 & 1559 & $1237-1856$ & 1495 & $1241-1841$ & 0.385 \\
\hline CD19 & 164 & $102-218$ & 174 & $112-248$ & 0.414 \\
\hline $\mathrm{CD}^{-} \mathrm{CD}^{-} 6^{+}$ & 132 & $82-195$ & 122 & $95-161$ & 0.632 \\
\hline $\mathrm{CD}^{+} \mathrm{CD}^{+}$ & 899 & $715-1145$ & 878 & $704-1110$ & 0.567 \\
\hline $\mathrm{CD}^{+} \mathrm{CD}^{+}$ & 488 & $373-593$ & 481 & $391-599$ & 0.646 \\
\hline $\mathrm{CD}^{+} \mathrm{CD}^{+} 6^{+}$ & 74 & $40-112$ & 47 & $25-98$ & 0.255 \\
\hline \multicolumn{6}{|l|}{ Leucocytes (cells/ $\mu \mathrm{l})$} \\
\hline Neutrophil & 6520 & $4940-8440$ & 6615 & $5210-8023$ & 0.798 \\
\hline Lymphocytes & 2220 & $1810-2560$ & 2180 & $1900-2573$ & 0.240 \\
\hline Monocytes & 579 & $450-673$ & 564 & $484-6634$ & 0.783 \\
\hline Eosinophils & 175 & $94-252$ & 243 & $155-327$ & 0.016 \\
\hline Basophils & 30 & $18-56$ & 37 & $25-58$ & 0.429 \\
\hline \multicolumn{6}{|c|}{ Immunoglobulins (mg/l) } \\
\hline $\lg G$ & 7750 & $6460-9570$ & 8200 & $6920-10200$ & 0.412 \\
\hline $\lg \mathrm{G} 1$ & 4780 & $3820-5690$ & 4730 & $3590-5860$ & 0.976 \\
\hline IgG2 & 2150 & $1690-2680$ & 2330 & $1940-2900$ & 0.386 \\
\hline $\operatorname{lgG} 3$ & 280 & $150-440$ & 300 & $210-390$ & 0.773 \\
\hline $\operatorname{lgG} 4$ & 220 & $120-380$ & 290 & $180-530$ & 0.101 \\
\hline $\lg A$ & 1640 & $1220-2060$ & 1810 & $1310-2530$ & 0.095 \\
\hline IgM & 1220 & $850-1550$ & 1100 & $710-1570$ & 0.399 \\
\hline $\operatorname{lgE}(\mathrm{IU} / \mathrm{ml})$ & 26 & $12-73$ & 54 & $19-165$ & 0.017 \\
\hline \multicolumn{6}{|c|}{ Complement components (mg/l) } \\
\hline Complement C3 & 1340 & $1170-1620$ & 1380 & $1190-1590$ & 0.170 \\
\hline Complement C4 & 230 & $190-320$ & 250 & $170-330$ & 0.813 \\
\hline
\end{tabular}

Th1, T helper type 1; Th2, T helper type 2; Tc1, cytotoxic T cell type 1; Tc2, cytotoxic T cell type 2.

${ }^{*} P$ values were obtained using the Mann-Whitney $U$ test

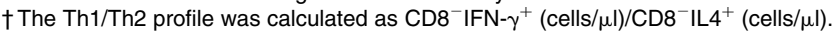

$\ddagger$ The Tc1/Tc2 profile was calculated as CD8 ${ }^{+} \mathrm{IFN}-\gamma^{+}(\mathrm{cells} / \mu \mathrm{l}) / \mathrm{CD} 8^{+} \mathrm{IL}-4^{+}(\mathrm{cells} / \mu \mathrm{l})$.

NK and NK T-like $\left(\mathrm{CD} 3^{+} \mathrm{CD} 56^{+}\right)$cells were not excluded in the analysis. Since these cells are high producers of IFN- $\gamma^{(27)}$, a bias in the Th1/Th2 and Tc1/Tc2 profiles could occur, although this effect was probably limited due to the low numbers of these cells in peripheral blood ${ }^{(27)}$.

Another explanation for this divergence could be that our population was a group of women who had just given birth. During pregnancy the maternal immune system is modified to avoid rejection of the fetus, although the precise mechanisms of the maternal immune system are not fully understood ${ }^{(28)}$. To protect the newborn, the mother's immunity undergoes complex changes during pregnancy and the puerperium. Thus, it is possible that the effects of fermented milk with $L$. casei in these mothers were lower and different from those observed in other circumstances. The survival of the fetus seems to depend significantly on the modulation of the immune response to avoid the occurrence of rejection ${ }^{(29)}$. To explain this phenomenon, it has been proposed in pregnant mice ${ }^{(7,30)}$ that immune modulation during successful pregnancy is Th2related, with the predominance of humoral Th2-type immunity and a decline of cell-mediated Th1-type immunity. Previous studies have proven that $\mathrm{Th} 2$ responses are prevalent in the peripheral blood of pregnant women. Thus, Kruse et al. ${ }^{(3)}$ studied the mRNA expression in lymphocytes from peripheral blood of pregnant women throughout the pregnancy and in the puerperium and compared these findings with those observed in non-pregnant women. These authors observed that the IL-4/IFN- $\gamma$ relationship was significantly higher in the first and second trimester of pregnancy than during the puerperium or in non-pregnant women. Using another methodology (flow cytometry), Reinhard et al. ${ }^{(4)}$ observed an increase of IL- $4^{+}-$ secreting $\mathrm{CD}^{+}{ }^{+} \mathrm{T}$ cells and a decrease of IFN- $\gamma^{+}$-secreting $\mathrm{CD} 4{ }^{+} \mathrm{T}$ cells in pregnant women as compared with non-pregnant women. Other researchers evaluated the differences in cytokine production among women with normal pregnancies and women with repeated abortions. Likewise, Hill et al. ${ }^{(5)}$ observed that peripheral blood mononuclear cells from women with repeated abortions, activated with trophoblastic extracts, produced mainly IFN- $\gamma$, while those from women with normal pregnancies produced mostly IL-10. These data have been corroborated by another group ${ }^{(6)}$ who observed that phytohaemagglutinin-activated peripheral blood mononuclear from women with normal pregnancies produced Th2 cytokines, while the Th1 cytokine production was increased in women with repeated abortions. The postpartum period has been thought of as a time for immunological recovery from the profound immunological changes of pregnancy. This could induce a complex immunological response attenuating the effects of L. casei on the systemic immune response during the puerperium.

According to other studies ${ }^{(26)}$, the study of the lymphocyte subpopulations showed a significant increase of the number of NK cells in the $L$. casei group. NK cells are involved in the specific and non-specific mechanisms of defence, and both $\mathrm{NK}$ and $\mathrm{NK} \mathrm{T}$ cells are high producers of IFN- $\gamma$. NK cells are part of the first line of the individual defence 
Table 3. Effects of milk supplementation with Lactobacillus casei (LC) on biological parameters during the overall study period (Median values and 25th to 75th percentiles (p25-p75))

\begin{tabular}{|c|c|c|c|c|c|c|c|c|c|c|}
\hline \multirow[b]{3}{*}{ Parameters } & \multicolumn{4}{|c|}{ Absolute variation (visit $2-$ visit 1$)^{\star}$} & \multirow[b]{3}{*}{$P \ddagger$} & \multicolumn{4}{|c|}{ Absolute variation (visit $3-$ visit 1$) \dagger$} & \multirow[b]{3}{*}{$P \ddagger$} \\
\hline & \multicolumn{2}{|c|}{ LC $(n 58)$} & \multicolumn{2}{|c|}{ Placebo ( $n$ 42) } & & \multicolumn{2}{|c|}{ LC $(n 58)$} & \multicolumn{2}{|c|}{ Placebo ( $n 41)$} & \\
\hline & Median & p25-p75 & Median & p25-p75 & & Median & p25-p75 & Median & p25-p75 & \\
\hline Th1/Th2 profile§ & 0.7 & $0.03-1.5$ & 0.7 & $-0.3-1.4$ & $0.978 \|$ & 0.7 & $-0.2-1.9$ & 0.9 & $0.04-2 \cdot 8$ & 0.624 \\
\hline Tc1/Tc2 profile & 3.9 & $0.4-20 \cdot 3$ & 1.4 & $-3 \cdot 1-19 \cdot 2$ & 0.123 & 3.6 & $-5 \cdot 9-18 \cdot 4$ & 5.9 & $-4.4-34.0$ & 0.630 \\
\hline \multicolumn{11}{|c|}{ 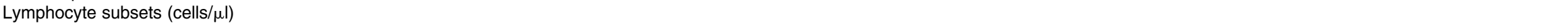 } \\
\hline CD3 & $178 \cdot 0$ & $-146-319$ & $156 \cdot 0$ & $-124 \cdot 0-465 \cdot 0$ & $0.502 \|$ & $316 \cdot 0$ & $-44.0-500 \cdot 0$ & $140 \cdot 0$ & $-2 \cdot 0-520 \cdot 0$ & $0.613 \|$ \\
\hline CD19 & -5.0 & $-38 \cdot 0-53 \cdot 0$ & -2.5 & $-32.5-64.8$ & 0.700 & 11.5 & $-20 \cdot 3-38 \cdot 8$ & $12 \cdot 5$ & $-48 \cdot 8-62 \cdot 5$ & 0.845 \\
\hline $\mathrm{CD}^{+} \mathrm{CD}^{+}{ }^{+}$ & 60.5 & $-98 \cdot 2-251.5$ & $47 \cdot 0$ & $-65 \cdot 3-296 \cdot 3$ & 0.727 & $146 \cdot 0$ & $-49 \cdot 0-297 \cdot 0$ & $140 \cdot 0$ & $-42 \cdot 0-291 \cdot 0$ & $0.853 \|$ \\
\hline $\mathrm{CD}^{+}{ }^{\mathrm{CD}} 8^{+}$ & 60.5 & $-27 \cdot 0-127 \cdot 5$ & 63.5 & $-42 \cdot 3-157 \cdot 3$ & 0.650 & 98.0 & $14 \cdot 0-189 \cdot 0$ & $44 \cdot 0$ & $-48 \cdot 0-168 \cdot 0$ & $0.129 \|$ \\
\hline \multicolumn{11}{|l|}{ 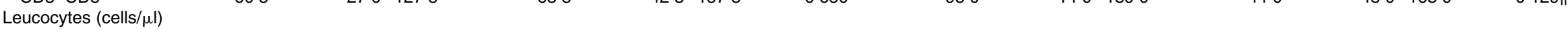 } \\
\hline Neutrophils & -2550 & $-4170--1080$ & -2540 & $-3722--1020$ & 0.757 & -2780 & $-4730--1495$ & -3225 & $-4835--1767$ & 0.551 \\
\hline Lymphocytes & $230 \cdot 0$ & $-110 \cdot 0-470 \cdot 0$ & $250 \cdot 0$ & $27 \cdot 5-622 \cdot 5$ & 0.296 & 295.0 & $-5 \cdot 0-612 \cdot 0$ & $280 \cdot 0$ & $5 \cdot 0-610 \cdot 0$ & $0.715 \|$ \\
\hline Monocytes & $-117 \cdot 0$ & $-304 \cdot 0--38.0$ & $-126 \cdot 0$ & $-234--34.5$ & 0.788 & -74.5 & $-165 \cdot 8-41 \cdot 0$ & $-81 \cdot 0$ & $-178.5-1.0$ & 0.800 \\
\hline Eosinophils** & $15 \cdot 1$ & $-21 \cdot 6-114 \cdot 6$ & $10 \cdot 0$ & $-24 \cdot 29-37 \cdot 0$ & 0.221 & -2.9 & $-32 \cdot 1-64 \cdot 2$ & $-25 \cdot 7$ & $-46 \cdot 5-45 \cdot 2$ & 0.084 \\
\hline Basophils & 1.0 & $-17 \cdot 0-25 \cdot 0$ & -3.5 & $-22 \cdot 8-24 \cdot 0$ & 0.589 & 0.0 & $-17 \cdot 3-16 \cdot 3$ & 2.5 & $-28 \cdot 5-16 \cdot 0$ & 0.831 \\
\hline \multicolumn{11}{|c|}{ Complement components (mg/l) } \\
\hline Complement C3 & -110 & $-290-60$ & -60 & $-325-82$ & $0.389 \|$ & -310 & $-483--76$ & -240 & $-450--75$ & $0.764 \|$ \\
\hline Complement $\mathrm{C} 4$ & 20 & $-42-77$ & 19 & $-49-75$ & $0.781 \|$ & -24 & $-71-19$ & -23 & $-80-31$ & $0.724 \|$ \\
\hline \multicolumn{11}{|c|}{ Immunoglobulins (mg/l) } \\
\hline $\lg G$ & 1680 & $1100-2500$ & 2140 & $1080-2900$ & 0.430 & 2810 & $2070-4010$ & 2680 & $1810-3590$ & $0.869 \|$ \\
\hline $\lg G 1$ & 1220 & $510-1790$ & 1230 & $650-2020$ & 0.547 & 1150 & $-233-2135$ & 1520 & $470-2240$ & 0.236 \\
\hline $\lg G 2$ & 620 & $320-850$ & 750 & $300-1350$ & 0.147 & 760 & $110-1430$ & 920 & $350-1690$ & $0.287 \|$ \\
\hline $\lg G 3$ & 47 & $20-120$ & 64 & $25-118$ & 0.589 & 86 & $-16-160$ & 38 & $-15-130$ & $0.331 \|$ \\
\hline $\lg G 4$ & 36 & $-1-74$ & 63 & $13-132$ & 0.041 & 18 & $-17-131$ & 78 & $10-221$ & 0.056 \\
\hline $\lg A$ & 370 & $180-640$ & 380 & $250-680$ & $0.653 \|$ & 234 & $-45-570$ & 230 & $-72-555$ & $0.545 \|$ \\
\hline $\operatorname{lgM}$ & 250 & $100-380$ & 310 & $110-520$ & 0.239 & 138 & $-25-403$ & 162 & $-10-387$ & $0.806 \|$ \\
\hline $\lg E^{\star \star}$ & -35 & $-252-105$ & -2 & $-175-97$ & 0.478 & -112 & $-369-90$ & -185 & $-395-8$ & 0.338 \\
\hline
\end{tabular}

Th1, T helper type 1; Th2, T helper type 2; Tc1, cytotoxic T cell type 1; Tc2, cytotoxic $\mathrm{T}$ cell type 2.

"Absolute variation between the values at $10 \mathrm{~d}$ and $3 \mathrm{~d}$ postpartum.

† Absolute variation between he values at $45 \mathrm{~d}$ and $3 \mathrm{~d}$ postpartum.

§ The Th1/Th2 profile was calculated as CD8 ${ }^{-}$IFN- $\gamma^{+}$(cells/ $\left./ \mathrm{ll}\right) / \mathrm{CDB}^{-} \mathrm{IL}-4^{+}$(cells/ $\left.\mu \mathrm{l}\right)$.

$\| P$ value was obtained using the $t$ test.

** Due to the basel difference buted as CDB 

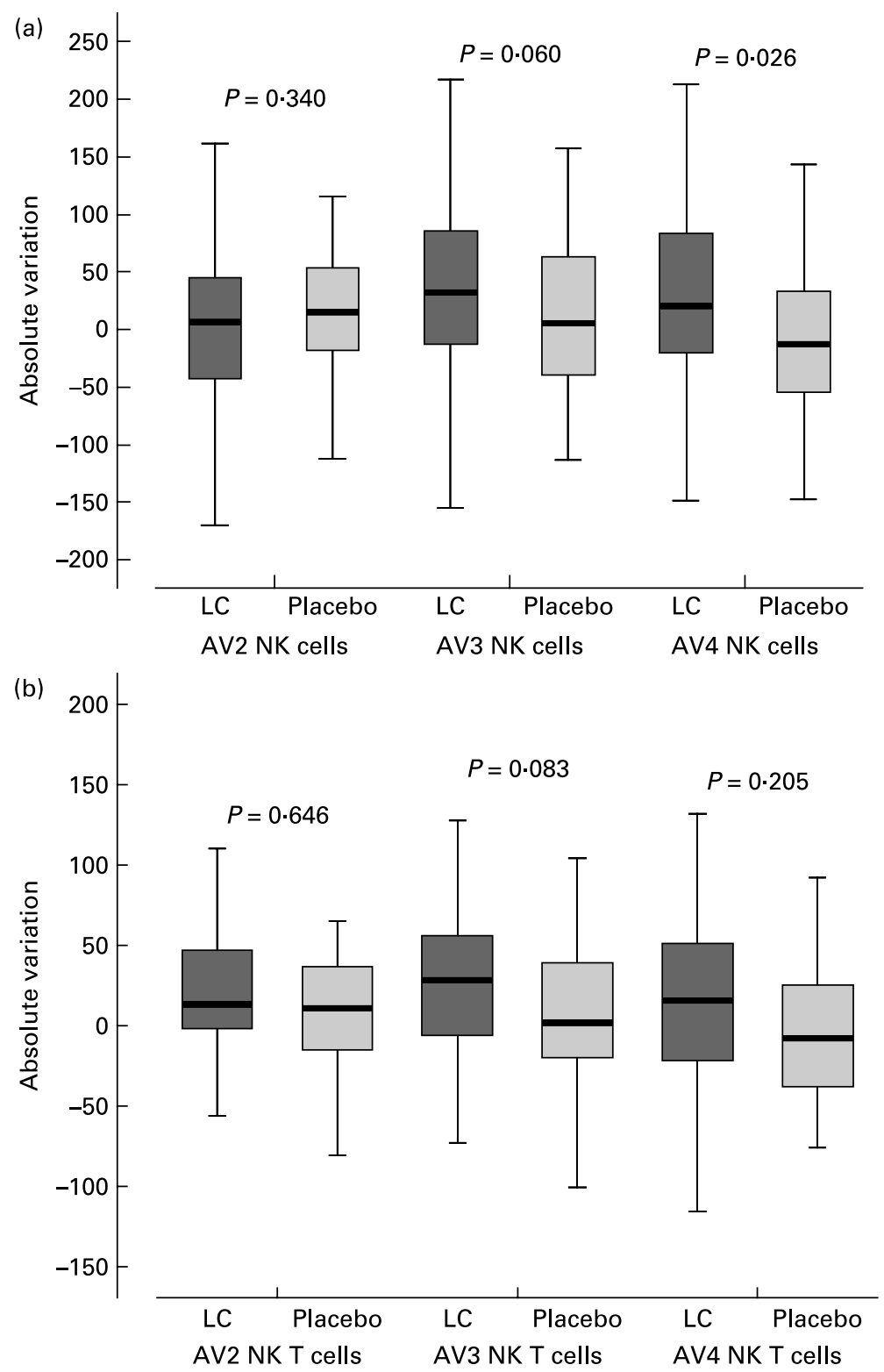

Fig. 3. Effects of milk supplementation with Lactobacillus casei (LC) on natural killer (NK) cells $\left(\mathrm{CD}^{-} \mathrm{CD} 56^{+}\right)(\mathrm{a})$ and $\mathrm{NK}^{\mathrm{T}-\text { like }}$ cells $\left(\mathrm{CD} 3^{+} \mathrm{CD} 56^{+}\right)(\mathrm{b})$ during the overall study period. AV2, absolute variation between the values at $10 \mathrm{~d}$ and $3 \mathrm{~d}$ postpartum; AV3, absolute variation between the values at $45 \mathrm{~d}$ and $3 \mathrm{~d}$ postpartum; AV4, absolute variation between the values at $45 \mathrm{~d}$ and $10 \mathrm{~d}$ postpartum. Values (horizontal bars) are medians and the boxes represent the 25 th to 75 th percentiles. The values outside vertical bars are considered outliers. $P$ values were obtained using the Mann-Whitney $U$ test.

barrier, together with macrophages and polymorphonuclear cells. In agreement with previous reports ${ }^{(26,31)}$, we observed a higher $\mathrm{AV}$ in the number of $\mathrm{CD}^{+}, \mathrm{CD} 19^{+}$and $\mathrm{CD}^{+}$ $\mathrm{T}$ cells in the $L$. casei group, although these changes did not reach statistical significance.

No significant differences between the treatment and the control groups were found in plasma immunoglobulin concentration over the 6 weeks. These finding are in contrast with previous reports ${ }^{(32,33)}$. Regarding $\operatorname{IgG}$ and IgE, the present results showed that the AV of IgG2, IgG4 and IgE concentrations (only significant for IgG4) decreased between visits 1 and 3 in the L. casei group. A possible explanation of these findings could be a lower Th2 activity in the intervention group, as has been previously suggested in other studies with probiotics $^{(31,33)}$.
In the overall period, no significant differences were found in the TGF- $\beta 1$, TGF- $\beta 2$, IL- $1 \beta$, IL-6, IL-8, IL-12 and IgA changes in the breast milk aqueous phase. TGF- $\beta$ is mainly produced by $\mathrm{T}$ helper type 3 cells $^{(34)}$. The suppressive and regulator actions of these cells in the development of allergy and immunological tolerance in the gastrointestinal tract have been emphasised. As such, probiotics have demonstrated the ability to revert the increment of the intestinal permeability and to increase the specific IgA intestinal response, promoting its mechanisms of barrier defence. Thus, several groups have evaluated probiotic effects on children with atopic eczema and food allergy, in which these mechanisms are altered ${ }^{(35-37)}$. Some probiotics have been shown to contribute to the processing of food antigens and to reduce their allergenicity in vitro and in vivo studies. Another study observed that administering 

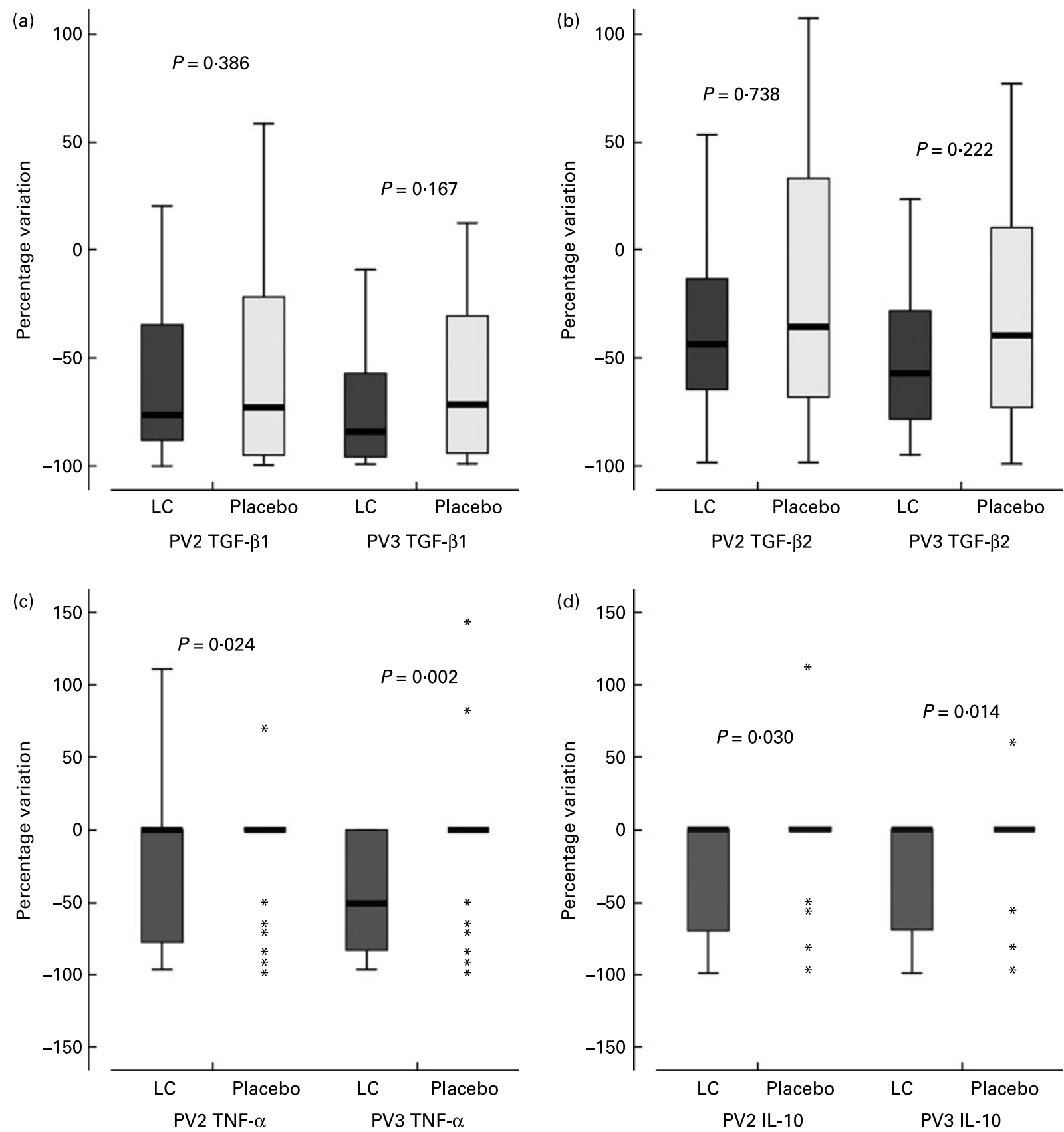

Fig. 4. Percentage variation of cytokines in breast milk in Lactobacillus casei (LC) and placebo groups. Percentage variation was calculated due to the basal difference in TNF- $\alpha$ and IL-10 concentrations between groups. PV2, percentage variation between the values at $10 \mathrm{~d}$ and $3 \mathrm{~d}$ postpartum; PV3, percentage variation between the values at $45 \mathrm{~d}$ and $3 \mathrm{~d}$ postpartum; TGF- $\beta$, transforming growth factor- $\beta$. Values (horizontal bars) are medians and the boxes represent the 25 th to 75th percentiles. The values outside vertical bars are considered outliers. In (c) and (d) outlier values for the placebo group are shown ( $\left.{ }^{*}\right)$. $P$ values were obtained using the Mann-Whitney $U$ test.

probiotics to pregnant and lactating mothers increased the immunoprotective potential of breast milk by increasing the TGF- $\beta$ concentrations in mother's milk ${ }^{(38)}$. This finding was not seen in the present study.

Borruel et al. ${ }^{(39)}$ studied the probiotic effects on TNF- $\alpha$ liberation by intestinal mucus, as TNF- $\alpha$ carries out a key function on the pathogenicity of intestinal inflammation in Crohn's disease. They found that TNF- $\alpha$ liberation by irritated mucus in Crohn's disease decreased significantly after the culture with L. casei or L. bulgaricus. These results are in line with the present study where a significant decrease of the percentage variation in TNF- $\alpha$ concentration in breast milk between visits 1 and 3 in the L. casei group was observed. However, these results should be taken with caution since the concentrations of IL-10 and TNF- $\alpha$ in milk samples were near the detection limit of the technique. The TNF- $\alpha$ concentrations in colostrum are in positive agreement with the results obtained by Takahata et al. ${ }^{(40)}$. However, the percentage of positive samples was higher $(77 \%)$ than those detected in the present study $(64 \%)$. Nevertheless, the work presented 
Table 4. Infant follow-up (proportions)

\begin{tabular}{|c|c|c|c|c|c|c|}
\hline \multirow[b]{2}{*}{ Parameters } & \multicolumn{2}{|c|}{$0-2$ months } & \multirow[b]{2}{*}{$P^{*}$} & \multicolumn{2}{|c|}{$2-6$ months } & \multirow[b]{2}{*}{$P^{*}$} \\
\hline & LC $(n 54)$ & Placebo $(n 38)$ & & $\mathrm{LC}(n 51)$ & Placebo (n 37) & \\
\hline Breast-fed (\%) & $92 \cdot 6$ & $81 \cdot 6$ & 0.929 & $52 \cdot 9$ & $40 \cdot 5$ & 0.250 \\
\hline Nursery school (\%) & - & - & - & 3.9 & $10 \cdot 8$ & 0.206 \\
\hline Medication use (\%) & 88.9 & 89.5 & 0.929 & 74.5 & 91.9 & 0.037 \\
\hline Respiratory symptoms (\%) & $13 \cdot 0$ & $10 \cdot 5$ & 0.495 & $33 \cdot 3$ & $16 \cdot 2$ & 0.071 \\
\hline Gastrointestinal symptoms (\%) & 51.9 & $63 \cdot 2$ & 0.281 & 29.4 & $54 \cdot 1$ & 0.020 \\
\hline Allergies (\%) & - & - & - & $3 \cdot 9$ & $5 \cdot 4$ & 0.174 \\
\hline Dermatitis (\%) & $25 \cdot 9$ & $36 \cdot 8$ & 0.263 & $21 \cdot 6$ & $37 \cdot 8$ & 0.095 \\
\hline
\end{tabular}

by Hawkes et al. ${ }^{(41)}$ showed higher ranges of detection, but the percentage of positive samples was lower. Hawkes et al. ${ }^{(41)}$ could determine $37 \%$ of positive samples in colostrum, $25 \%$ in early milk and $22 \%$ in mature milk. In our data, $64 \%$ of positive samples in colostrum and $40 \%$ in early and $30 \%$ in mature milk were detected. The analysis of cytokines in the present study was carried out by means of the cytometric bead array technique. To our knowledge, this is the first time this technique has been used to analyse breast milk. It was quite complicated to work with the colostrum samples, since it is a very dense substance with a high percentage of fat that was necessary to eliminate. The use of the novel technique could explain the different percentages of positive samples detected.

From a clinical perspective, others have suggested a beneficial effect of probiotics on the paediatric population $^{(33,38,42-45)}$. We observed that $L$. casei consumption was associated with a lower incidence of gastrointestinal episodes and a lower medication rate in infants from 2 to 6 months. Other studies have suggested that probiotic use in children produces benefits in the remission of symptoms of diarrhoea, food allergies, and dermatitis ${ }^{(33,38,42)}$. In addition, our findings could stimulate future research in which the main hypothesis of study would be to prove the benefits for children of the consumption of fermented milk with $L$. case $i$ during pregnancy and lactation.

We acknowledge that the relative absence of functional analyses of T, NK and B cells may be a limitation of the present study. The main variable, the Th1/Th2 profile, was assessed by means of a functional study such as the study of IFN- $\gamma$ - and IL-4-producing $\mathrm{T}$ cells after polyclonal activation. However, no functional analyses of B and NK cells were carried out, although data from several studies would minimise these limitations: the immunoglobulin changes may be an indirect measurement of B cell function, and a positive correlation between NK cell numbers and NK activity in immunocompetent individuals exists ${ }^{(46,47)}$

Another possible limitation of the present study is the number of women lost to follow-up. However, the motivation of pregnant and lactating women was very high as was the participation rate. Moreover, the number of women lost to follow-up was not significant. There were six drop-outs in the control group of which two were due to lack of adherence to treatment. The number of drop-outs was five in the intervention group (three attributed to lack of adherence).
To our knowledge this is the first randomised, double-blind clinical trial presenting results about the effects of $L$. casei during the puerperium on immunomodulation of healthy lactating mothers. In conclusion, the present results are the first step to assess the role of $L$. casei on this special population and on their children. These findings make it possible to identify those immunological markers that are more appropriate to assess the role of probiotics on the immune response during lactation. Future research involving larger populations and longer follow-up periods could definitively confirm or reject our findings.

\section{Acknowledgements}

The authors wish to thank all the mothers and their infants participating in the study, as well as the midwives of Primary Health Care for their collaboration. The authors would like to acknowledge the methodological technical assistance from Professor José Luis Pérez-Arellano from the Infectious Disease Unit of the Hospital Universitario Insular de Gran Canaria, Marian Fabreas, Ana María Lamas and Marta Riaño Ruíz from the Biochemistry Laboratory of the Hospital Universitario Insular de Gran Canaria and Maria Cárdenas Bilbao and Ayoze García Saavedra from the Immunology Laboratory of the Hospital Universitario Dr Negrin de Gran Canaria. A particular acknowledgement is made for Magdalena Villanueva Cabrera on behalf of The Canarian ProBreastfeeding Association. Special thanks to Joy Ngo, RD for her help in editing the English version of the manuscript.

The present study was supported by Danone S. A. through a research contract with the University Foundation of Las Palmas.

None of the authors had a conflict of interest, except J. C. who works for Danone S. A.

A. O.-A. was involved in the study design, coordinated the fieldwork, processed the data, did the statistical analysis, interpreted the data and drafted the manuscript. L. S.-M. obtained the funding, initiated and supervised the project, designed the study and reviewed the manuscript. A. S.-V. supervised the statistical analysis and reviewed the manuscript. C. R.-G. was involved in the cytokine assays, processing of breast milk samples and reviewed the manuscript. O. R. and J. G. recruited the subjects. L. P.-Q. and M. S. were responsible for the children's evaluation. A. L. and T. M. were responsible 
for the lymphocyte subsets and haematological analyses. A. S. was responsible for the immunoglobulin analyses. F. C. was involved in the randomisation and distribution of the study products. J. C. was involved in the study design, supervised the project and reviewed the manuscript. L. P.-Q. and T. M. commented on the manuscript.

\section{References}

1. Aagaard-Tillery KM, Silver R \& Dalton J (2006) Immunology of normal pregnancy. Semin Fetal Neonatal Med 11, 279-295.

2. Makhseed M, Raghupathy R, Azizieh F, Omu A, Al-Shamali E \& Ashkanani L (2001) Th1 and Th2 cytokine profiles in recurrent aborters with successful pregnancy and with subsequent abortions. Hum Reprod 16, 2219-2226.

3. Kruse N, Greif M, Moriabadi NF, Marx L, Toyka KV \& Rieckmann P (2000) Variations in cytokine mRNA expression during normal human pregnancy. Clin Exp Immunol 119, $317-322$.

4. Reinhard G, Noll A, Schlebusch H, Mallmann P \& Ruecker AV (1998) Shifts in the Th1/Th2 balance during human pregnancy correlate with apoptotic changes. Biochem Biophys Res Comm 245, 933-938.

5. Hill JA, Polgar K \& Anderson DJ (1995) T-helper 1-type immunity to trophoblast in women with recurrent spontaneous abortion. JAMA 273, 1933-1936.

6. Raghupathy R, Makhseed M, Azizieh F, Hassan N, Al-Azemi M \& Al-Shamali E (1999) Maternal Th1- and Th2-type reactivity to placental antigens in normal human pregnancy and unexplained recurrent spontaneous abortions. Cell Immunol 196, $122-130$.

7. Chaouat G, Menu E, Clark DA, Dy M, Minkowski M \& Wegmann TG (1990) Control of fetal survival in $\mathrm{CBA} \times \mathrm{DBA} / 2$ mice by lymphokine therapy. J Reprod Fertil 89, 447-457.

8. Wilder RL (1998) Hormones, pregnancy, and autoimmune diseases. Ann N Y Acad Sci 840, 45-50.

9. Zimmer JP, Garza C, Butte NF \& Goldman AS (1998) Maternal blood B-cell $\left(\mathrm{CD} 19^{+}\right)$percentages and serum immunoglobulin concentrations correlate with breast-feeding behavior and serum prolactin concentration. Am J Reprod Immunol 40, $57-62$.

10. Zimmer JP, Garza C, Heller ME, Butte NF \& Goldman AS (1996) Relationship between serum prolactin, lactation and changes in maternal blood $\mathrm{B}$-cell $\left(\mathrm{CD} 19^{+}\right)$percents during the first 8 months post-partum. J Reprod Immunol 30, 81-95.

11. Zimmer JP, Garza C, Heller ME, Butte NF \& Goldman AS (1998) Postpartum maternal blood helper $\mathrm{T}\left(\mathrm{CD}^{+} \mathrm{CD}^{+}\right)$and cytotoxic $\mathrm{T}\left(\mathrm{CD} 3^{+} \mathrm{CD} 8^{+}\right)$cells: correlations with iron status, parity, supplement use, and lactation status. Am J Clin Nutr 67, 897-904

12. Salminen SJ, Gueimonde M \& Isolauri E (2005) Probiotics that modify disease risk. J Nutr 135, 1294-1298.

13. Erickson KL \& Hubbard NE (2000) Probiotic immunomodulation in health and disease. $J$ Nutr 130, Suppl. 2, S403-S409.

14. O'Sullivan GC, Kelly P, O'Halloran S, Collins C, Collins JK, Dunne C \& Shanahan F (2005) Probiotics: an emerging therapy. Curr Pharm Des 11, 3-10.

15. Perdigon G, Fuller R \& Raya R (2001) Lactic acid bacteria and their effect on the immune system. Curr Issues Intest Microbiol 2, 27-42.

16. Isolauri E, Sutas $Y$, Kankaanpaa $P$, Arvilommi H \& Salminen $S$ (2001) Probiotics: effects on immunity. Am J Clin Nutr 73, Suppl. 2, S444-S450.
17. Lopez-Varela S, Gonzalez-Gross M \& Marcos A (2002) Functional foods and the immune system: a review. Eur J Clin Nutr 56, Suppl. 3, S29-S33.

18. Maassen CB, van Holten-Neelen C, Balk F, den Bak-Glashouwer MJ, Leer RJ, Laman JD, Boersma WJ \& Claassen E (2000) Straindependent induction of cytokine profiles in the gut by orally administered Lactobacillus strain. Vaccine 18, 2613-2623.

19. Spanhaak S, Havenaar R \& Schaafsma G (1998) The effect of consumption of milk fermented by Lactobacillus casei strain Shirota on the intestinal microflora and immune parameters in humans. Eur J Clin Nutr 52, 899-907.

20. Matsuzaki T (1998) Immunomodulation by treatment with Lactobacillus casei strain Shirota. Int J Food Microbiol 41, 133-140.

21. Kato I, Tanaka K \& Yokokura T (1999) Lactic acid bacterium potently induces the production of interleukin-12 and interferon$\gamma$ by mouse splenocytes. Int J Immunopharmacol 21, 121-131.

22. Hori T, Kiyoshima J, Shida K \& Yasui H (2002) Augmentation of cellular immunity and reduction of influenza virus titer in aged mice fed Lactobacillus casei strain Shirota. Clin Diagn Lab Immunol 9, 105-108.

23. Bautista-Garfias CR, Ixta-Rodriguez $\mathrm{O}$, Martínez-Gómez $\mathrm{F}$, López MG \& Aguilar-Figueroa BR (2001) Effect of viable or dead Lactobacillus casei organisms administered orally to mice on resistance against Trichinella spiralis infection. Parasite 8, Suppl. 2, S226-S228.

24. Nagao F, Nakayama M, Muto T \& Okumura K (2000) Effects of a fermented milk drink containing Lactobacillus casei strain Shirota on the immune system in healthy human subjects. Biosci Biotechnol Biochem 64, 2706-2708.

25. Rigotti E, Piacentini GL, Ress M, Pigozzi R, Boner AL \& Peroni DG (2006) Transforming growth factor- $\beta$ and interleukin-10 in breast milk and development of atopic diseases in infants. Clin Exp Allergy 36, 614-618.

26. Marcos A, Warnberg J, Nova E, Gomez S, Alvarez A, Alvarez R, Mateos JA \& Cobo JM (2004) The effect of milk fermented by yogurt cultures plus Lactobacillus casei DN-114001 on the immune response of subjects under academic examination stress. Eur J Nutr 43, 381-389.

27. Bendelac A, Savage PB \& Teyton L (2007) The biology of NKT cells. Аnпu Rev Immunol 25, 297-336.

28. Pearson H (2002) Reproductive immunology: immunity's pregnant pause. Nature 420, 265-266.

29. Gustafsson C, Hummerdal P, Matthiesen L, Berg G, Ekerfelt C \& Ernerudh J (2006) Cytokine secretion in decidual mononuclear cells from term human pregnancy with or without labour: ELISPOT detection of IFN- $\gamma$, IL-4, IL-10, TGF- $\beta$ and TNF- $\alpha$. J Reprod Immunol 71, 41-56.

30. Shimaoka Y, Hidaka Y, Tada H, Nakamura T, Mitsuda N, Morimoto Y, Murata Y \& Amino N (2000) Changes in cytokine production during and after normal pregnancy. Am J Reprod Immunol 44, 143-147.

31. Matsuzaki T \& Chin J (2000) Modulating immune responses with probiotic bacteria. Immunol Cell Biol 78, 67-73.

32. Fang H, Elina T, Heikki A \& Seppo S (2000) Modulation of humoral immune response through probiotic intake. FEMS Immunol Med Microbiol 29, 47-52.

33. Rinne M, Kalliomaki M, Arvilommi H, Salminen S \& Isolauri E (2005) Effect of probiotics and breastfeeding on the bifidobacterim and lactobacillus/enterococcus microbiota and humoral immune responses. J Pediatr 147, 186-191.

34. Faria AM \& Weiner HL (2006) Oral tolerance: therapeutic implications for autoimmune diseases. Clin Dev Immunol 13, 143-157.

35. Bottcher MF, Jenmalm MC, Garofalo RP \& Bjorksten B (2000) Cytokines in breast milk form allergic and nonallergic mothers. Pediatr Res 47, 157-162. 
36. Oddy WH, Halonen M, Martinez FD, Lohman IC, Stern DA, Kurzius-Spencer M, Guerra S \& Wright AL (2003) TGF- $\beta$ in human milk is associated with wheeze in infancy. $J$ Allergy Clin Immunol 112, 723-728.

37. Bottcher MF, Jenmalm MC \& Bjorkstén B (2003) Cytokine, chemokine and secretory IgA levels in human milk in relation to atopic disease and IgA production in infants. Pediatr Allergy Immunol 14, 35-41.

38. Rautava S, Kalliomaki M \& Isolauri E (2002) Probiotics during pregnancy and breast-feeding might confer immunomodulatory protection against atopic disease in the infant. $J$ Allergy Clin Immunol 109, 119-121.

39. Borruel N, Carol M, Casellas F, Antolin M, de Lara F, Espin E, Naval J, Guarner F \& Malagelada JR (2002) Increased mucosal tumour necrosis factor $\alpha$ production in Crohn's disease can be downregulated ex vivo by probiotic bacteria. Gut 51, 659-664.

40. Takahata Y, Takada H, Nomura A, Ohshima K, Nakayama H, Tsuda T, Nakano H \& Hara T (2001) Interleukin-18 in human milk. Pediatr Res 50, 268-272.

41. Hawkes JS, Bryan DL, James MJ \& Gibson RA (1999) Cytokines (IL- $1 \beta$, IL- 6 , TNF- $\alpha$, TGF- $\beta 1$, and TGF- $\beta 2$ ) and prostaglandin E2 in human milk during the first three months postpartum. Pediatr Res 46, 194-199.
42. Isolauri E, Arvola T, Sutas Y, Moilanen E \& Salminen S (2000) Probiotics in the management of atopic eczema. Clin Exp Allergy 30, 1604-1610.

43. Mastretta E, Longo P, Laccisaglia A, Balbo L, Russo R, Mazzaccara A \& Gianino P (2002) Effect of Lactobacillus GG and breast-feeding in the prevention of rotavirus nosocomial infection. $J$ Pediatr Gastroenterol Nutr $\mathbf{3 5}$, $527-531$.

44. Lin HC, Su BH, Chen AC, Lin TW, Tsai CH, Yeh TF \& Oh W (2005) Oral probiotics reduce the incidence and severity of necrotizing enterocolitis in very low birth weight infants. Pediatrics $115,1-4$.

45. Schultz M, Gottl C, Young RJ, Iwen P \& Vanderhoof JA (2004) Administration of oral probiotic bacteria to pregnant women causes temporary infantile colonization. J Pediatr Gastroenterol Nutr 38, 293-297.

46. Shakhar K, Rosenne E, Loewenthal R, Shakhar G \& Carp H (2006) High NK cell activity in recurrent miscarriage: what are we really measuring? Hum Reprod 21, 2421-2425.

47. Shakhar K, Ben-Eliyahu S, Loewenthal R, Rosenne E \& Carp H (2003) Differences in number and activity of peripheral natural killer cells in primary versus secondary recurrent miscarriage. Fertil Steril 80, 368-375. 